\title{
Optimization of Urban Cargo Distribution Network and Station Points with Open Source GIS
}

\author{
Şevket BEDİROĞLU ${ }^{* 1}$ ORCID $0000-0002-7216-6910$ \\ ${ }^{1}$ Gaziantep University, Faculty of Architecture, City and Regional Planning Department, \\ Gaziantep
}

Geliş tarihi: 27.07.2021 Kabul tarihi: 10.12.2021

Atıf şekli/ How to cite: BEDIROĞLU, Ş., (2021). Optimization of Urban Cargo Distribution Network and Station Points with Open Source GIS. Çukurova Üniversitesi, Mühendislik Fakültesi Dergisi, 36(4), 989995.

\begin{abstract}
The cargo and transportation sector is growing day by day. Resources need to be managed more efficiently in the face of growth in the sector and fast delivery demand in customer requests. Location selection of cargo branches and route planning processes of cargo vehicles are important in order to manage resources more efficiently. Geographic Information Systems (GIS) provide significant advantages in site selection and route planning processes. Especially open source GIS data and GIS software offer low cost and effective solutions. In this study, the branch locations of a cargo company in Şehitkamil district of Gaziantep province were examined and the routes of the vehicles were analyzed in a way to minimize time loss and fuel consumption. In this context, isochrone maps were produced over the road network. The population numbers within these isochrone zones were calculated and vehicle liability zones were determined according to the population data. Finally, the daily route planning of more than a hundred cargoes, which are required to be delivered by cargo vehicles in one day, has been made.
\end{abstract}

Keywords: GIS, Open source GIS, Cargo and transportation, Isochrone maps

\section{Açık Kaynak CBS ile Şehiriçi Kargo İstasyon Noktalarının Optimizasyonu ve Dağıtım Planlaması}

$\ddot{\mathbf{O} z}$

Kargo ve taşımacılık sektörü her geçen gün daha da büyümektedir. Sektördeki büyüme ve müşteri isteklerindeki hızlı teslimat talebi karşısında kaynakların daha verimli yönetilmesi gerekmektedir. Kaynakların daha verimli yönetilebilmesi için kargo şubelerinin yer seçimi ve kargo araçlarının güzergah planlama süreçleri önem arz etmektedir. Yer seçimi ve güzergah planlama sürecinde Coğrafi Bilgi Sistemleri (CBS) önemli avantajlar sağlamaktadır. Özellikle açık kaynak kodlu CBS verileri ve CBS yazılımları düşük maliyetli ve etkin çözümler sunmaktadır. Bu çalışmada Gaziantep ilinin Şehitkamil ilçesinde bir kargo firmasının şube yerleri irdelenmiş ve araçlara ait güzergahlar zaman kaybını ve yakıt

*Sorumlu (Corresponding author) yazar: Şevket BEDİROĞLU, sevketbediroglu@gmail.com 
tüketimini en aza indirecek şekilde analiz edilmiştir. Bu kapsamda yol ağı üzerinden isochrone haritalar üretilmiş. Bu isochrone bölgeleri içerisinde var olan nüfus sayıları hesaplanmış ve nüfus verilerine göre araç sorumluluk bölgeleri belirlenmiş̧ir. Son olarak ta kargo araçlarının bir gün içerisinde teslimat yapması gereken yüzün üzerinde kargonun günlük rota planlaması yapılmıştır.

Keywords: CBS, Açık kaynak CBS, Kargo ve taşimacilik, Isochrone harita

\section{INTRODUCTION}

The increasing mobility of people represents another constraint to successful delivering. Ecommerce brings changes to consumer behavior and parcel delivery requirements in regard to reliability, speed, mobility and proximity [1]. Ecommerce has increased in recent years and reached its peak due to the pandemic for the last 2 years. According to the forecasts, the need for the cargo sector will increase due to e-commerce and other causes in the following years. Smart transportation systems should be used due to increasing needs and high demand for effective resource management. Some important components of smart transportation systems are the site selection (location) of cargo stations and daily route planning.

The most significant reason for applying network analysis and route planning to transportation is that businesses are interested in determining the best routes to minimize cost and time [2, 3]. Logistic problems are common to many industry segments; thus, many applications for GIS in addressing or supporting logistical problem solving can be cited [4].

GIS can both model transportation networks, and integrate the association of network characteristics directly into a database. In this regard, finding the fast routes for the delivery of fresh vegetables takes into account different parameters as its impedance [3]. Combining GIS and Decision Support Systems provides us with the advantages of both and allows a better modeling of the vehicle routing problem which is also a spatial problem [5]. The integration of logistical constraints is inevitable in the context of sustainable development, because it optimizes the exchange of physical flows between the links and it helps to resolve the localization problem [6].

In recent literature there are various successful studies at related areas. Some of these studies are shown in Table 1. Abousaeidi et al., 2016 [3] have researched GIS based methods for determining fastest delivery routes. Akter et al., 2018 [7] have studied on, open source GIS tools for determining freight activity patterns. Azaz, 2011 [4] has investigated role of GIS in logistics and other business sectors. Widoningram, 2015 [8] has studied on GIS based approach for catchment and service area analysis. Wong et al., 2020 [9] have focused on sustainable freight transportation with graph-theory based road connectivity assessment. $\mathrm{Yu}$ et al., 2015 [10] have focused on implementation of GIS based smart logistics. Yücel and Ulutaş, 2009 [11] have studied site selection of cargo stations with GIS and MCDM. Chandro et al., 2019 [12] have studied freight transportation planning with GIS based approach. EL Raouini et al., 2018 [5] have studied freight distribution and transportation planning with GIS based approach. Chiquileri et al., 2019 [13] have focused on GIS based solution for vehicle routing problem. Kazhakmetov and Zakiev, 2020 [14] aimed implementing GIS technologies for logistics management.

Timely delivery of cargo and optimum management of resources in urban cargo transportation is an important problem concerning spatial sciences. At this point, GIS has provided effective tools from the past to the present. Today, there are new generation open source data sets and analysis programs that are highly efficient, easy to use and economical. The main purpose of the study is to make urban cargo transportation processes more efficient with these new generation systems. With the developed system, time and fuel consumption were tried to be reduced. 
Table 1. Literature review

\begin{tabular}{|l|l|}
\hline Author(s)-Date & Subject, purpose or methodology \\
\hline Abousaeidi et al., 2015 & GIS based methods for determining fastest delivery routes \\
\hline Akter et al., 2018 & Open source GIS tools for determining freight activity patterns \\
\hline Azaz, 2011 & Investigated role of GIS in logistics and other business sectors \\
\hline Widoningram, 2015 & GIS based approach for catchment and service area analysis \\
\hline Wong et al., 2020 & $\begin{array}{l}\text { Sustainable freight transportation with graph-theory based road } \\
\text { connectivity assessment }\end{array}$ \\
\hline Yu et al., 2015 & Implementation of GIS based smart logistics \\
\hline Yücel and Ulutaş, 2010(?trh) & Site selection of cargo stations with GIS and MCDM \\
\hline Chandro et al., 2019 & Freight transportation planning with GIS based approach \\
\hline EL Raouini et al., 2018 & $\begin{array}{l}\text { Freight distribution and transportation planning with GIS based } \\
\text { approach }\end{array}$ \\
\hline Chiquileri et al., 2019 & GIS based solution for vehicle routing problem \\
\hline Kazhakmetov and Zakiev, 2020 & Implementing GIS technologies for logistics management \\
\hline
\end{tabular}

\section{MATERIAL AND METHODS}

\subsection{Study Area}

Şehitkamil district of Gaziantep province was chosen as the study area. Şehitkamil is a district of Gaziantep Province of Turkey (Figure 1). It is part of Gaziantep Metropolitan Municipality. The district has an area of $1,268 \mathrm{~km}^{2}$. Population of the district is 726,000 according to the 2015 census. Gaziantep OSB, which is among the largest organized industrial zones in Turkey, is located in the district, as well as an intense urbanization and housing area. The district has an intense activity in terms of logistics and transportation activities, both individually and institutionally.

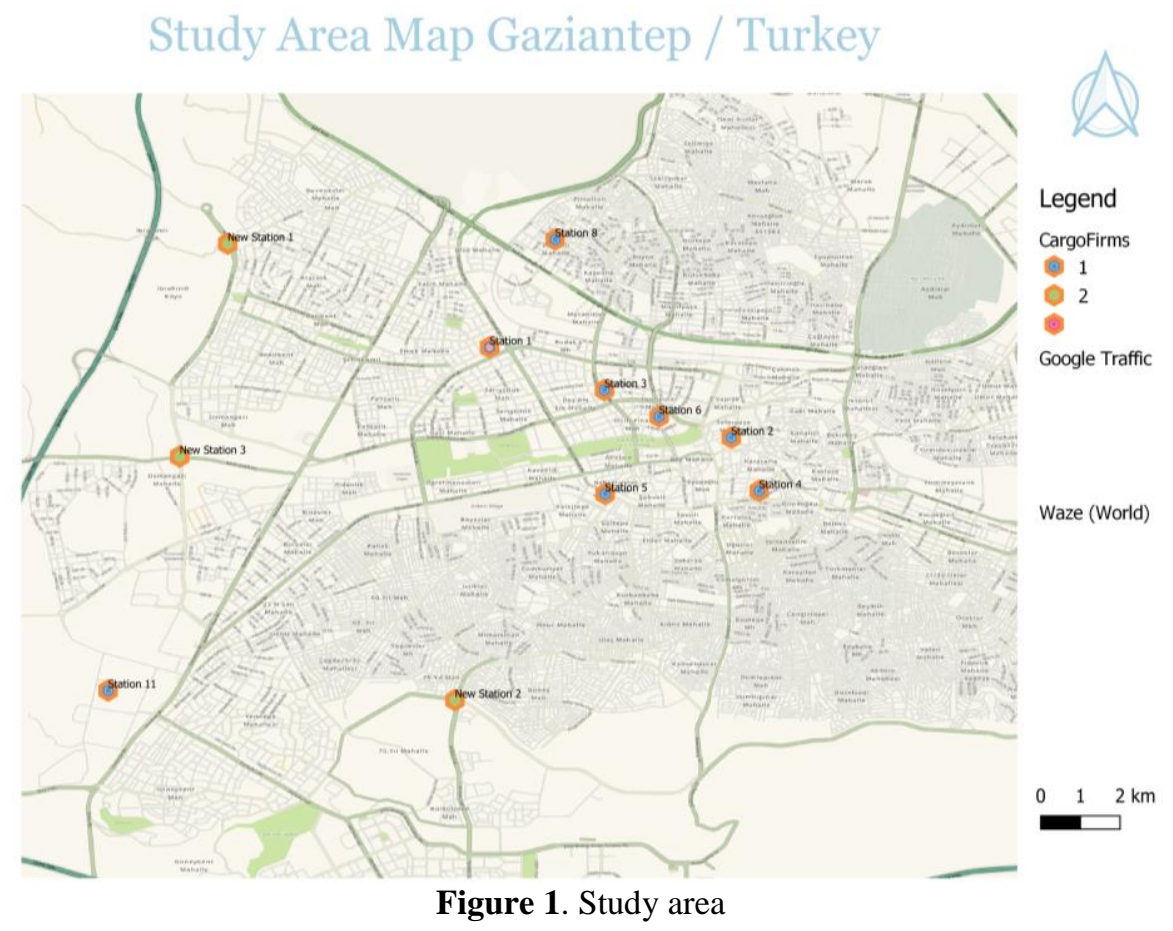




\subsection{Data Used and Produced Within the Scope of the Study}

The geographical data used and produced within the scope of the study are as follows. First of all, the road network map of the study area was provided to include width, traffic density and direction information. The points belonging to the cargo company were determined and entered into the GIS environment. The building and population data in the region were taken instantly from open source data systems (OSM).

\subsection{Determination of Optimum Location Selection Methods, Efficiency Analysis of Branch Locations}

Choosing the right station point is one of the most important components of cargo companies in their urban distribution processes. The heterogeneous distribution of stations without considering population and traffic data will cause problems in resource management. There are different GISbased alternative methods for site selection. Methods such as multi-criteria decision making, service area layer, and accessibility analysis are among the efficient methods frequently encountered in the literature. In this study, isochrone maps of each existing station were created by creating a balance between the traffic and population in the road network while choosing the cargo stations location. An isochrone map in geography and urban planning is a map that depicts the area accessible from a point within a certain time threshold [15]. Isochrone maps are especially used to produce simultaneous driving maps. Application areas has diversity such as public transportation, cargo planning, address accessibility, school shuttle-vehicle route planning, hiking trip planning. There are different production methods such as raw point layer, $2 \mathrm{~d}$ interpolation, Alpha shapes and convex hull. Figure 2 shows the isochrone maps of each station.

\section{Study Area and Isochrone Zones Calculated over Road Network}

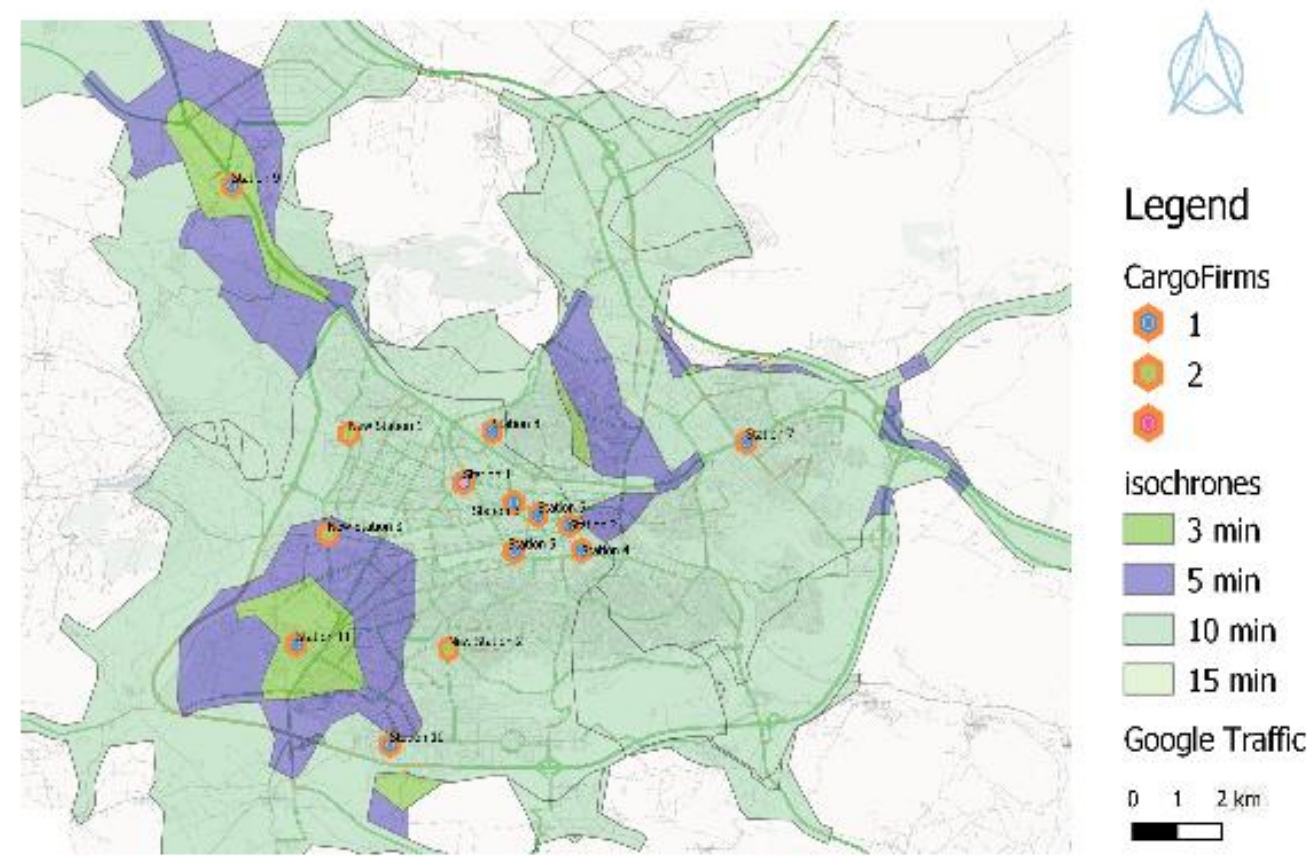

Figure 2. Isochrone map of current and suggested stations in study area 


\subsection{Determination of Responsibility Areas of Vehicles}

There are 6 to 8 vehicles on average at cargo stations in Turkey, and each vehicle carries approximately 100 goods during the day. During the pandemic process, the number of urban goods transported on a vehicle basis sometimes exceeded
150. In such intense processes and in general use, it is important to analyze the responsibility areas of cargo vehicles correctly. In order to solve this problem efficiently, the access zones of the cargo vehicles at 5, 10 and 15 minutes distance and the population values in these access zones are calculated over open route service (Figure 3 ).

\section{Station 1 Temporal Truck Driving Areas and Populations in Temporal Isochrone Areas}

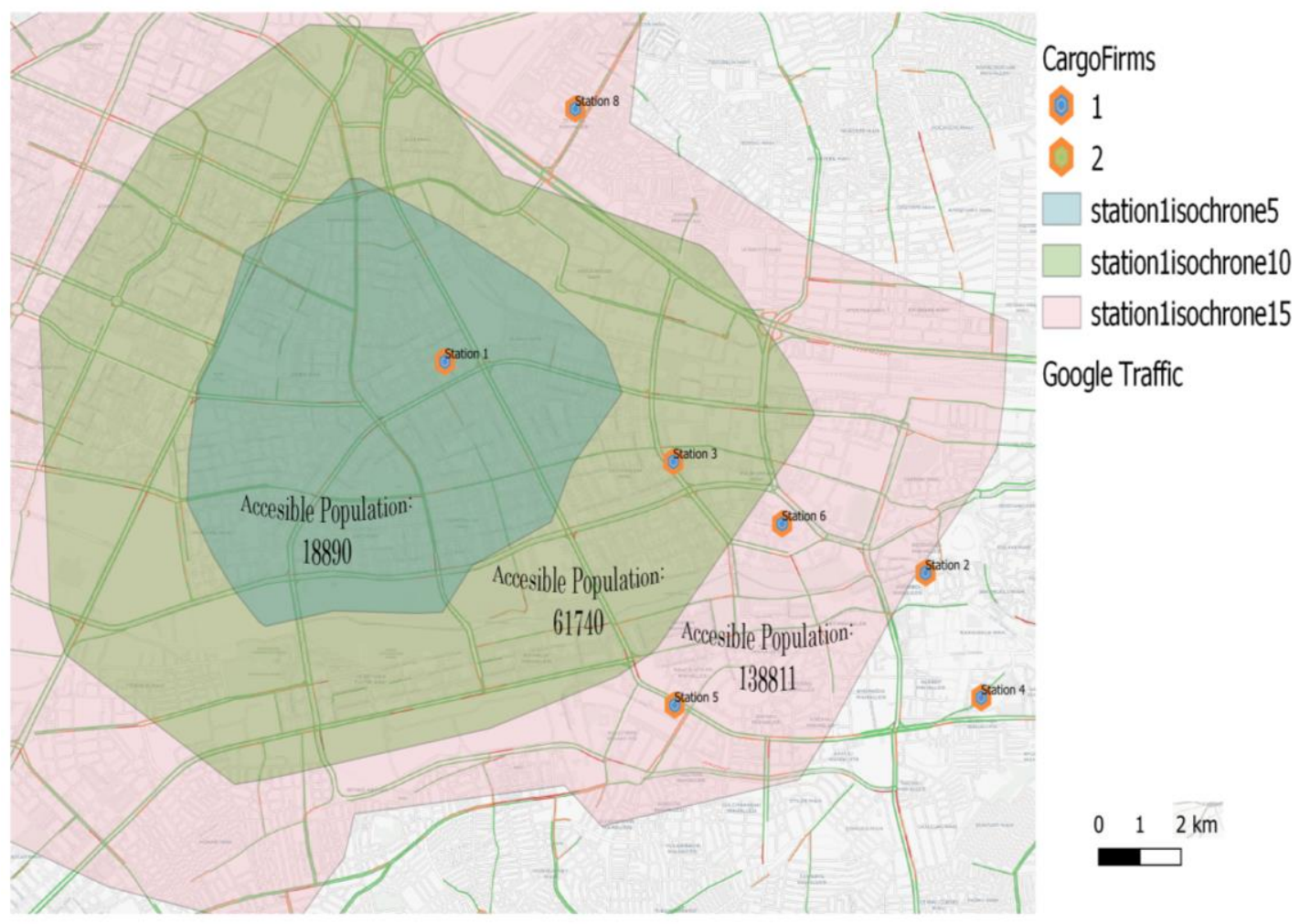

Figure 3. Temporal access zones of stations and population in zones

2.5. Preparation of Detailed Distribution Plans of Vehicles According to the Road Network

At this stage, the most important problem is to plan the distribution plan of cargoes, whose daily geographical distribution consists of different points, in a way that reduces time and fuel loss. The daily cargo data is not in a static structure, but in a dynamic structure data is updated every day. The route that the cargo allocated to the vehicles will follow during the day will significantly affect the efficiency. In order to solve this critical problem, network analyzes were made over the road route and distribution plans were prepared (Figure 4). In addition, the distance matrix was calculated between the daily cargoes and the cargo route. 


\section{Parcel / Cargo Distrubution Plan of a Truck for One Chosen Day}
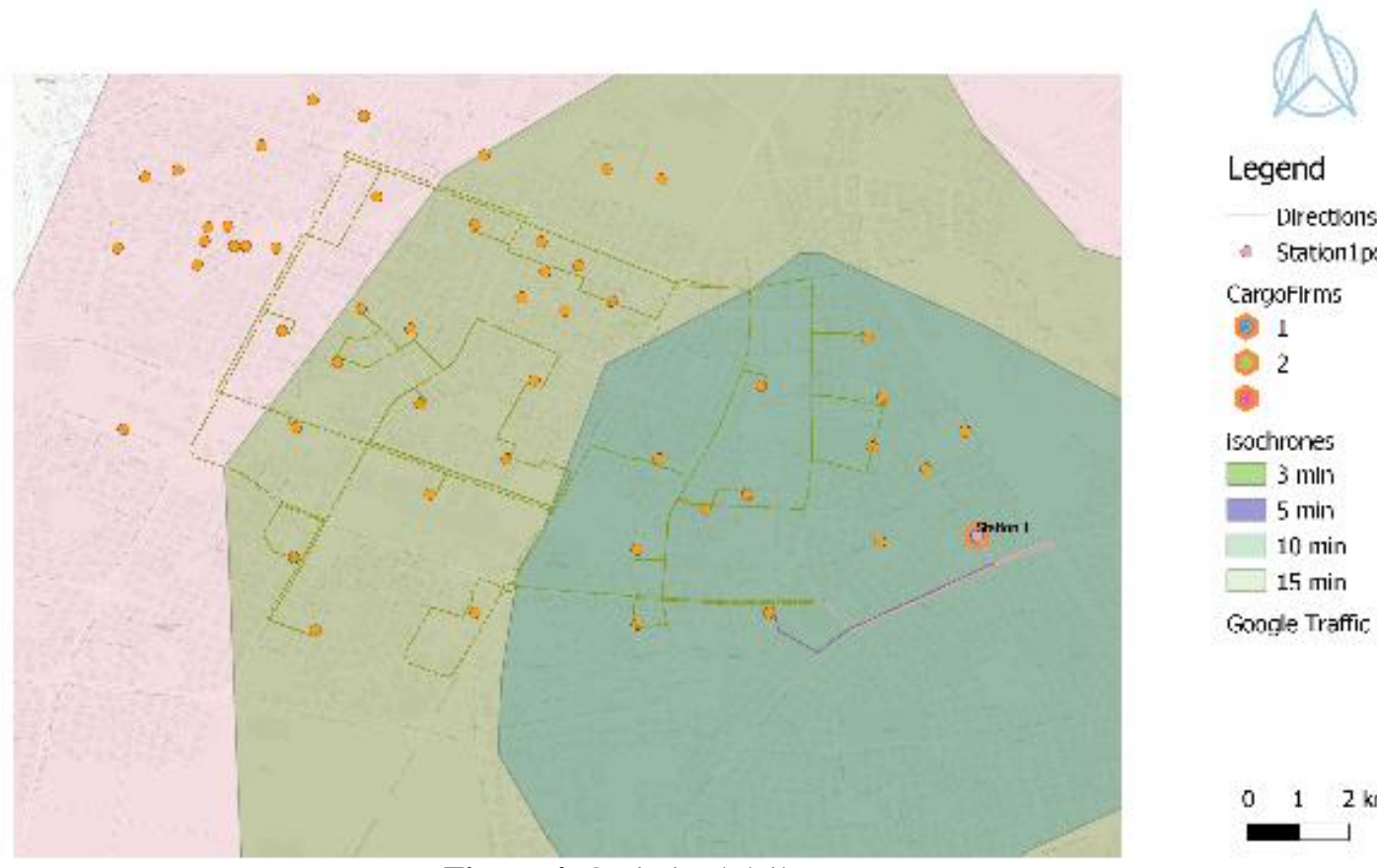

Legend

Directions

a Station1 point

Carcoflirms

1

02

당

isochinones

$\square 3 \mathrm{mIn}$

5 min

10 min

— 15 min

Google Traffic

Figure 4. Optimized daily cargo route

\section{DISCUSSION AND RESULTS}

The importance of the logistics cargo sector has been increasing in recent years and the sector continues to grow, especially with the pandemic process. Factors such as the location of cargo stations and the correct planning of the routes of cargo vehicles have critical importance in the process. The developed system and the rich geographic analysis capabilities offered by the GIS from the past to the present have further increased its functionality. Today, using web-based GIS systems that enable instant decision making process makes significant contributions. At this point, open source data, web services and open source programs are in a position to make critical contributions to the business world.

The isochrone maps produced with the developed system and case studies provide significant advantages over the classical buffer method in the decision-making process. Thanks to isochrone maps, alternatives that establish ideal correlations between population, road length and traffic density parameters can be produced.

Open source data is changing business models because it is available at any time. The selection of the study area reduces the difficulties in the data acquisition process in the analysis and decisionmaking processes. On the other hand, although some data have some deficiencies in terms of reliability and verification, verification systems are developed day by day and errors are reduced.

Finally, studies have shown that GIS is an important tool for cargo companies that want to reduce losses by making resource management more efficient and increase customer satisfaction by reducing time losses.

\section{REFERENCES}

1. İndap, Ş., 2019. The Status of Cargo Companies in E-Commerce Logistics and Innovative Solution Proposals to Improve 
Their Competitiveness. Girişimcilik ve İnovasyon Yönetim Dergisi, 8(2), 39-67.

2. Memon, I. A., 2005. Application of Geographic Information System in Transportation for Road Network Analysis (M.Sc). Universiti Teknologi Malaysia, Faculty of Civil Engineering.

3. Abousaeidi, M., Fauzi R., Muhamad, R., 2016. Geographic Information System (GIS) Modeling Approach to Determine the Fastest Delivery Routes. Saudi J Biol Sci 23:555-564. https://doi.org/https://doi.org/10.1016/j.sjbs.20 15.06.004.

4. Azaz L., 2011. The Use of Geographic Information Systems (GIS) in Business. International Conference on Humanities. Geography and Economics (ICHGE'2011) Pattaya Dec., 2011

5. El Raoui H, Oudani M, Alaoui AEH., 2018. ABM-GIS Simulation for Urban Freight Distribution of Perishable Food. MATEC Web Conf.

6. Sassi, E., Benabdelhafid, A., 2020. The Complexity of the Territorial Logistics Ecosystem. 13ème Conference Internationale de Modelisation, Optimisation et Simulation (MOSIM2020), 12-14 Nov 2020, AGADIR, Maroc, Nov 2020, AGADIR (virtual), Morocco.

7. Akter, T., Hernandez, S., Diaz Corro, K., Ngo, C., 2018. Leveraging Open-source GIS Tools to Determine Freight Activity Patterns from Anonymous GPS Data.

8. Widaningrum, D.L., 2015. A GIS-based Approach for Catchment Area Analysis of Convenience Store. Procedia Comput Sci 72, 511-518.

9. Wong, E.Y.C., Tai, A.H., So, S., 2020. 'Container Drayage Modelling with Graph Theory-based Road Connectivity Assessment for Sustainable Freight Transportation in New Development Area. Computers and Industrial Engineering, 149(106810), 1-11. doi.org/10.1016/j.cie.2020.106810.

10. Yu, Y.W., Jung, H., Bae, H., 2015. Integrated GIS-based Logistics Process Monitoring Framework with Convenient Work Processing Environment for Smart Logistics. ETRI J 37, 306-316. doi.org/10.4218/etrij.15.2314.00 56.
11. Yücel, M.M., Ulutaş, A., 2009. Çok Kriterli Karar Yöntemlerinden Electre Yöntemiyle Malatya'da Bir Kargo Firması için Yer Seçimi. Sosyal Ekonomik Araştırmalar Dergisi, no.17, 327-344.

12. Chandra, A., Pani, A., Sahu, P.K., 2020. Designing Zoning Systems for Freight Transportation Planning: A GIS-based Approach for Automated Zone Design Using Public Data Sources. Transp Res Procedia 48:605-619. https://doi.org/10.1016/j.trpro. 2020.08.063.

13. Cecílio, I., Chiquieri, J., Freitas, R., Goncalves, W., 2019. Holistic Analysis of the Vehicle Routing Problem: an Approach for GIS-T. Int J Adv Eng Res Sci, 6, 116-131. https://doi.org/10.22161/ijaers.69.13.

14. Kozhakhmeto, S., Zakiev, E., 2020. Possible Ways to Implement GIS Technologies in the Logistics Management System in Order to Improve Management Efficiency. International Journal of Advanced Research in Engineering and Technology (IJARET) Volume 11, Issue 12, December 2020, 1546-1554.

15. Allen, J., 2018. Using Network Segments in the Visualization of Urban Isochrones. Cartogr Int J. Geogr. Inf Geovisualization, 53, 262-270. https://doi.org/10.3138/cart.53.4. 2018-0013. 
